\title{
Gender and age disparities in the associations of occupational factors with alcohol abuse and smoking in the French working population
}

\author{
S. Legleye ${ }^{\text {a,b,c,* }}$, M. Baumann ${ }^{\text {d }}$, P. Peretti-Watel ${ }^{\text {e }}$, F. Beck ${ }^{\text {f,g }}$, N. Chau ${ }^{\text {b,c }}$ \\ ${ }^{a}$ Institut national des études démographiques (Ined), 133, boulevard Davout, 75020 Paris, France \\ ${ }^{\mathrm{b}}$ Inserm, U669, 75014 Paris, France \\ ${ }^{\mathrm{c}}$ UMR-S0669, University Paris-Sud and University Paris Descartes, 75014 Paris, France \\ ${ }^{\mathrm{d}}$ University of Luxembourg, INtegrative research unit on Social and Individual DEvelopment (INSIDE), 7220 Walferdange, Luxembourg \\ ${ }^{\mathrm{e}}$ Inserm, UMR379, observatoire régional de la santé, région Provence-Alpes-Côte, 13006 Marseille, France \\ ${ }_{\mathrm{f}}^{\mathrm{f}}$ National Institute for Prevention and Health Education (INPES), 93218 Saint-Denis, France \\ ${ }^{\mathrm{g}}$ CNRS UMR 8136, Inserm, U611 Cesames, centre de recherche psychotropes, santé mentale, société, Univ Paris Descartes, 75005 Paris, France
}

Received 3 August 2010; accepted 9 February 2011

Available online 20 July 2011

\begin{abstract}
Background. - This study assessed the associations of short-term employment, physical and psychological occupational demands, and job dissatisfaction with alcohol abuse (using the Audit-C test) and daily smoking among working French men and women in different age groups.

Methods. - The sample included 13,241 working people, 18-29, 30-39, and 40-59-years-old, randomly selected in France and interviewed by phone. Occupation, type of employment, physical demands, psychological demands, job dissatisfaction, gender, age, educational level, and income were considered. Data were analyzed with logistic models.

Results. - Alcohol abuse affected $20.4 \%$ of men and $7.5 \%$ of women; smoking $32.1 \%$ and $24.2 \%$, respectively. Their patterns of association with the occupational factors varied with gender and age. Job dissatisfaction was the leading factor among young men (adjusted odds ratio for alcohol abuse and smoking: 1.71 and 2.02), whereas short-term employment was the leading factor among young women (1.69 and 1.58), this pattern being reversed in older generations. The pattern of associations of physical and psychological demands with outcomes is more complex, but overall psychological demands were more important for women (especially the younger ones) than men, especially for smoking (OR $>1.6$ ). Smoking within 5 min after waking was much more common among male and female smokers with these occupational factors, suggesting a potential dependency.

Conclusions. - Workers with short-term employment and occupational demands are subject to a higher risk for alcohol abuse and smoking with high gender and age disparities. Gender and age should be considered when designing measures to prevent substance abuse related to occupation.
\end{abstract}

(C) 2011 Elsevier Masson SAS. All rights reserved.

Keywords: Occupational demands; Short-term employment; Job dissatisfaction; Tobacco; Alcohol abuse; Gender; Age

\section{Résumé}

Position du problème. - Étude des associations entre conditions d'emploi (contrat à durée déterminée [CDD] ou d'intérim, contraintes physiques et psychologiques, insatisfactions relatives aux conditions de travail), usage abusif d'alcool (repéré par l'Audit-C) et tabagisme quotidien parmi des hommes et des femmes de différentes catégories d'âge.

Méthode. - L'échantillon aléatoire comprend 13241 personnes de 18-29, 30-39 et 40-59 ans exerçant un emploi en France, interrogées par téléphone en 2005. Revenu du foyer, niveau de diplôme et catégorie d'emploi ont été pris en compte en plus des conditions d'emploi citées. Les associations ont été estimées à l'aide de régressions logistiques.

Résultats. - L'abus d'alcool concernait 20,4\% d'hommes et 7,5\% de femmes, le tabagisme 31,2 et 24,2\%. Ces usages étaient associés aux conditions d'emploi étudiées de façon variable suivant le sexe et l'âge. Les facteurs les plus importants était l'insatisfaction pour les hommes jeunes $(\mathrm{OR}=1,71$ pour l'abus d'alcool et 2,02 pour le tabagisme) et l'emploi en CDD pour les femmes (1,69 et 1,58), ces associations s'inversant dans les générations plus âgées. L'association entre contraintes physiques et psychologiques et usages est apparue plus complexe, mais contrastée par âge et

\footnotetext{
* Corresponding author. Tel.: +33156062098.

E-mail address: stephane.legleye@ined.fr (S. Legleye).
} 
par sexe. Les contraintes psychologiques étaient les plus associées au tabagisme parmi les femmes de moins de 40 ans (OR $>1,6)$ alors que les contraintes physiques l'étaient le plus chez les hommes (OR proches de 1,3 pour les deux usages).

Conclusions. - La prévention devrait prendre en compte la variabilité des associations entre CDD, contraintes professionnelles et usages d'alcool et de tabac suivant l'âge et le sexe.

(C) 2011 Elsevier Masson SAS. Tous droits réservés.

Mots clés : Contraintes professionnelles ; Conditions de travail ; Abus d'alcool ; Tabagisme ; Genre

\section{Introduction}

Limiting alcohol abuse and tobacco smoking is a major public concern. Smoking and alcohol use contribute to 9.0 and $8.4 \%$, respectively, of diseases in the European Union [1]. Drinking and smoking are socially determined behaviors that can begin during adolescence [2], but they can also be ways for coping with adverse working conditions [1,3-5]. Many workers suffer from physical/psychological occupational demands, job insecurity, and job dissatisfaction and these situations have a strong influence on health [6]. Physical and psychological demands play a role in this process [7]. Workers who request a job change are more subject to work injuries [8] and remaining in that position results in alterations in cognitive processes, work abilities, risk perception, and increased stress [9], which can increase tobacco/alcohol use in order to cope [10-13]. Moreover, short-term employment is associated with hazardous work conditions and rapid turnover, which increases risk of work injury $[14,15]$, income erosion, job insecurity, and lack of prospects for promotion, leading to increased stress and job dissatisfaction [10-13]. In 2005, $14.5 \%$ of workers in the EU25 countries had a short-term contract [16].

However, some aspects are often neglected [17]. First, occupational epidemiology has paid less attention to women's problems than men's [18]. Occupational factors differ between genders: women are more likely to work on short-term contracts, to be employees/intermediate professionals, and men to be managers or manual workers/craftsmen, but domestic work and childcare are still women's tasks [19]. As physical and psychosocial factors are associated with substance use [4,20-22], this could explain a part of the differences in alcohol and tobacco use observed between genders. However, the relationships between gender, occupational conditions, and tobacco and alcohol use appear complex. In a previous study focusing on nonmanual jobs, gender differences were relatively small for tobacco use, but quite high for heavily alcohol use [23]. Roxburgh found that job demands had no effect on alcohol consumption among men, but had a strong effect on women [24]. Other researchers point out that pronounced male dominance of an occupation may be a source of stress and may therefore increase alcohol consumption among female workers [25]. Otten and colleagues found an inverse relationship between job control and smoking behaviors among men but not women [26] and they argued for a sex-specific approach in studying job-related stress smoking hazards.

Age disparities are also of interest, although even less studied. Young adulthood is an important period of development and adaptation to working life, during which health indicators (injury, homicide, substance use) reach a peak [27,28]. Every year, young people start work lacking job knowledge and experience, resulting in a higher work injury risk [27]. One study in northeastern France showed that high physical/psychological occupational demands favor smoking initiation or transition into intensive smoking during the first years of work $(<30$ years) [10]. On the other hand, workers aged 40 or more have a higher prevalence of physical/mental disabilities [29], limiting their ability to cope with occupational problems [30].

The potential impact of short-term employment on alcohol abuse and smoking may differ between genders and various age groups, because the need for job security increases when people get older, have children and progressively lose their ability to adapt. As a result, its association with tobacco and alcohol use could vary across these groups, but most studies did not consider this aspect because of limited sample size or target populations. One study on nonmanual full-time employees of a bank and a university in Britain found slight gender differences for smoking, while men drank more heavily [23]. One study in Toronto showed that job demands have no impact on men's alcohol use but increase women's drinking, while job noxiousness has no effect on women's alcohol use but increases men's use [24].

The present study investigated the associations between alcohol abuse and smoking with short-term employment, job dissatisfaction, as well as physical and psychological occupational demands among workers in France and explored gender and age disparities in these associations. The association between smoking on waking and these occupational factors were also evaluated among smokers as this behavior may reflect tobacco dependence [31]. The results may help large-scale prevention in working men and women of different age groups.

\section{Materials and methods}

\subsection{Study design}

This study was based on the data from the nationwide survey Health Barometer 2005, conducted from December 2004 to January 2005 among French people aged 12-75 years [32], using a two-stage sample frame (household/individual). Only one person in each household participated. Households with a land-line telephone (whether or not in the telephone directory) or a cellular telephone were eligible (86 and 14\%, respectively). This investigation was approved by the Commission Nationale Informatique et Libertés. 
The study protocol included: (a) a request to participate, explaining the objectives of the study that was delivered by mail or during the first telephone call (to subjects with unlisted numbers whose address was unknown); and (b) a telephone interview using Computer-Assisted Telephone Interview software (CATI). Unsuccessful calls were repeated 30 and $90 \mathrm{~min}$ later, up to 20 attempts, on different days and at different times. The selected individual in each household was the French speaking person aged 12-75 who had the nearest date of birth. A total of 30,514 people participated $(63.1 \%)$. The present study focused on 13,241 subjects aged 18-59, with a landline telephone, who were working at the time of the survey. Subjects having only a mobile phone were excluded as their questionnaire did not include working conditions. The implications of this limitation will be discussed below.

\subsection{Measures}

Outcome variables were daily tobacco use (cigarette/cigar/ pipe) and alcohol abuse measured with the Audit-C test [33], which consists in three questions assessing the frequency of alcohol use, the frequency of drinking more than five glasses of alcohol per day during the last 12 months and the mean number of drinks per drinking day. Smoking on waking was assessed with the question: "In the morning, how long after waking do you smoke your first cigarette?" ( $\leq 5$ min vs. 6-30/31-60/ $\geq 60 \mathrm{~min}$ ). The four occupational factors investigated were physical demands, psychological demands, job dissatisfaction, and short-term employment (including temporary job and interim work vs. permanent contract). They are commonly used in occupational epidemiology and all proved to be related to poor health [6], absence on the job, cardiovascular problems, and premature death [7,34,35]. Physical and psychological demands were addressed with these questions: "Would you say that your work is physically exhausting?" (Very much or quite vs. somewhat or not at all) and "Would you say that your work is psychologically exhausting?" (Very much or quite vs. somewhat or not at all). Dissatisfaction with working conditions was addressed with "Are you satisfied with your working conditions?" (Very or quite satisfied vs. quite or very dissatisfied). The consequences of the use of these general questions are discussed below.

The potential confounders were: occupation, age, educational level, marital status, and income [36]. All analyses were stratified for gender. Six occupational categories were considered, defined by the National Institute for Statistics and Economic Studies (INSEE): managers, intermediate occupations, employees, manual workers, farmers, and craftsmen. Age was categorized into four groups: < 30, 30-39, 4049 and $\geq 50$ years. The educational level was defined as the highest diploma and was divided into three categories: up to high school, 1st-4th year university level, and 5th year university level or higher. This scale derives from the International Standard Classification of Education (ISCED97) [37]. We also used the global equivalent household income (comprising salaries, allowances and other income of all household members) defined by a weighted scale that enables comparisons between households of different sizes and compositions. We used the Organization for Economic Cooperation and Development's scale: the first adult in the household is weighted 1 , each additional person aged 15 years old or older is weighted 0.5 and each person under 15 years of age is weighted 0.7 . The scale is categorized into four classes: less than 900, 900-1500, 1500 euros or more and unknown, the latter (around 10\%) considered as a proper category in the multivariate models.

\subsection{Data analysis}

The relationships between each outcome variable and the occupational factors were first assessed with the $\mathrm{Chi}^{2}$ independence test (Tables 1 and 2). Then four rounds of logistic regression models were run: first, by adjusting only for age; second, by including all covariates except the occupational category; third, by including all covariates; and fourth by stratifying by occupational category (Table 3). This procedure can assess the robustness of the results and evaluate potential overadjustment. We checked that there was no significant interaction between each of the four occupational factors studied and occupational category for alcohol abuse and tobacco smoking in both genders in the fully adjusted models that could have revealed differences in magnitude of the associations according to occupational category. Nevertheless, we explored the associations in managers and manual workers separately (which can be considered very different in occupational factors) because for men two interaction tests were close to significance ( $p$-values between 0.06 and 0.1 ). Percentages were weighted using the gender, age, and occupational category distributions of the French working general population as references but multivariate analyses were performed with unweighted data. The analyses were made separately for men and women, and finally for the three age groups, 18-29, 30-39 and 40+ years in Fig. 1. Additionally, we computed logistic regressions among smokers, modeling smoking during the first $5 \mathrm{~min}$ after waking up, which is important evidence of nicotine dependence [31] (Table 4). All analyses were conducted using the SAS V9.1 statistical package.

\section{Results}

The sample included 6,094 men and 7,147 women. Alcohol abuse affected $20.4 \%$ of the men and $7.5 \%$ of the women $(p<0.001)$, smoking 32.1 and $24.2 \%$, respectively $(p<0.001)$. Overall, $11.1 \%$ of men and $14.8 \%$ of women had short-term employment. Physical job demands affected $26.3 \%$ of men and $27.1 \%$ of women; psychological job demands 17.3 and $16.4 \%$, respectively; and job dissatisfaction 17.8 and $16.9 \%$, respectively.

Table 1 shows that alcohol abuse affected more farmers and manual workers among men, and more managers and farmers among women. Smoking affected more manual workers, craftsmen, employees, and intermediate professionals among men, and more craftswomen, manual workers, and employees 
Table 1

Prevalence $(\%)$ of alcohol abuse and smoking according to occupational factors and sociodemographic characteristics.

\begin{tabular}{|c|c|c|c|c|c|c|}
\hline & \multicolumn{3}{|c|}{ Men $(n=6094)$} & \multicolumn{3}{|c|}{ Women $(n=7147)$} \\
\hline & $N$ & Alcohol abuse & Smoking & $N$ & Alcohol abuse & Smoking \\
\hline \multicolumn{7}{|l|}{ Sociodemographic characteristics } \\
\hline Age (years) & & $p<0.001$ & $p<0.001$ & & $p<0.05$ & $p<0.001$ \\
\hline 18-29 & 1001 & 21.0 & 41.0 & 1132 & 7.7 & 29.4 \\
\hline $30-39$ & 2063 & 17.7 & 33.0 & 2286 & 6.0 & 26.8 \\
\hline $40-49$ & 1690 & 20.6 & 29.4 & 2005 & 8.2 & 23.3 \\
\hline $50-59$ & 1340 & 23.4 & 24.4 & 1724 & 8.4 & 16.0 \\
\hline Educational level & & $p<0.001$ & $p<0.001$ & & $p<0.001$ & $p<0.001$ \\
\hline Middle or high school & 2732 & 22.9 & 35.6 & 2864 & 6.7 & 28.1 \\
\hline $1^{\text {st }}-4^{\text {th }}$ year university & 2523 & 19.4 & 30.5 & 3670 & 7.3 & 22.3 \\
\hline $5^{\text {th }}$ year university or over & 740 & 13.9 & 21.2 & 613 & 12.6 & 13.5 \\
\hline Unknown & 99 & & & 0 & & \\
\hline Living alone & & $p<0.05$ & $p<0.001$ & & $p<0.05$ & $p<0.001$ \\
\hline Yes & 1778 & 22.5 & 38.6 & 2321 & 8.9 & 31.2 \\
\hline No & 4316 & 19.8 & 29.7 & 4826 & 7.0 & 21.6 \\
\hline \multicolumn{7}{|l|}{ Work characteristics } \\
\hline Occupational category & & $p<0.001$ & $p<0.001$ & & $p<0.001$ & $p<0.001$ \\
\hline Managers & 1223 & 19.2 & 23.4 & 1078 & 11.5 & 20.5 \\
\hline Intermediate professionals & 1500 & 19.9 & 30.8 & 2291 & 7.3 & 22.0 \\
\hline Manual workers & 1614 & 22.6 & 39.7 & 533 & 5.4 & 28.4 \\
\hline Employees & 932 & 17.6 & 31.0 & 2892 & 6.2 & 25.7 \\
\hline Craftsmen & 621 & 18.8 & 34.3 & 243 & 9.9 & 33.2 \\
\hline Farmers & 204 & 31.6 & 17.1 & 110 & 11.8 & 4.5 \\
\hline Type of employment & & $p<0.05$ & $p<0.001$ & & NS & $p<0.001$ \\
\hline Long-term employment & 5452 & 20.0 & 30.7 & 6129 & 7.3 & 23.2 \\
\hline Short-term employment & 642 & 23.6 & 39.8 & 1018 & 8.6 & 28.2 \\
\hline \multicolumn{7}{|l|}{ Occupational demands } \\
\hline Physical demands & & NS & $p<0.001$ & & NS & $p<0.001$ \\
\hline Yes & 1572 & 20.6 & 35.4 & 1992 & 7.9 & 29.1 \\
\hline No & 4522 & 20.3 & 30.3 & 5155 & 7.3 & 22.0 \\
\hline Psychological demands & & $p<0.05$ & $p<0.001$ & & NS & $p<0.001$ \\
\hline Yes & 1087 & 22.8 & 42.2 & 1187 & 8.4 & 29.2 \\
\hline No & 5007 & 19.8 & 29.3 & 5960 & 7.3 & 22.9 \\
\hline Job dissatisfaction & & $p<0.001$ & $p<0.001$ & & $p<0.05$ & $p<0.01$ \\
\hline Yes & 1083 & 23.8 & 38.0 & 1252 & 8.9 & 27.5 \\
\hline No & 5011 & 19.6 & 30.3 & 5895 & 7.2 & 23.1 \\
\hline \multicolumn{7}{|l|}{ Income } \\
\hline Equivalent monthly income (euros) & & $p<0.05$ & $p<0.001$ & & NS & $p<0.001$ \\
\hline$<900$ & 1008 & 18.2 & 34.1 & 1306 & 7.2 & 29.0 \\
\hline $900-1500$ & 1966 & 22.3 & 33.1 & 2500 & 6.9 & 23.2 \\
\hline$\geq 1500$ & 2598 & 19.8 & 28.8 & 2561 & 8.6 & 22.0 \\
\hline Unknown & 522 & 21.3 & 33.9 & 780 & 6.2 & 21.1 \\
\hline
\end{tabular}

among women. Alcohol abuse and smoking were more common among men and women with short-term employment (although the relation was nonsignificant for alcohol abuse among women). Physical and psychological demands and job dissatisfaction were related to smoking for both genders. Alcohol abuse was related to psychological demands and job dissatisfaction among men, and to job dissatisfaction among women. Alcohol abuse and smoking were related to all the socioeconomic covariates studied, except income, which was not related to alcohol abuse in women.

As Table 2 shows, short-term employment, physical and psychological demands, and job dissatisfaction affected all categories of occupations but differently for men and women. Short-term employment was more common among manual workers and employees of both genders. Physical job demands were found more in manual workers, farmers, and craftsmen among men, and manual workers, farmers, and employees among women. Psychologically demanding work was found more often in managers and intermediate professionals among women; the differences being small among men. Job dissatisfaction was reported more by manual workers for both genders.

Multivariate logistic models (Table 3) reveal that the men with physically demanding occupations, psychologically demanding occupations, job dissatisfaction, or short-term employment had a higher risk of smoking (OR, 1.22-1.32), and those with job dissatisfaction or short-term employment had a higher risk of alcohol abuse (OR, approximately 1.25). The women with short-term employment had a higher risk of alcohol abuse and smoking (ORs 1.36 and 1.20, respectively), 
Table 2

Association of occupational factors with job category (row \%).

\begin{tabular}{|c|c|c|c|c|c|}
\hline & $N$ & Short-term employment & Physical job demands & Psychological job demands & Job dissatisfaction \\
\hline \multicolumn{6}{|l|}{ Men } \\
\hline$p$-value & & 0.0001 & 0.0001 & 0.0368 & 0.0001 \\
\hline Managers & 1614 & 7.8 & 4.8 & 27.4 & 12.7 \\
\hline Intermediate professionals & 932 & 9.7 & 9.5 & 27.1 & 18.3 \\
\hline Manual workers & 204 & 13.5 & 31.5 & 23.4 & 20.2 \\
\hline Employees & 621 & 13.6 & 15.3 & 25.4 & 20.0 \\
\hline Craftsmen & 1500 & 7.9 & 24.5 & 27.9 & 15.6 \\
\hline Farmers & 1223 & 3.9 & 40.2 & 21.1 & 22.1 \\
\hline \multicolumn{6}{|l|}{ Women } \\
\hline$p$-value & & 0.0001 & 0.0001 & 0.0001 & 0.0001 \\
\hline Managers & 533 & 10.1 & 6.6 & 31.0 & 15.5 \\
\hline Intermediate professionals & 2892 & 10.7 & 10.1 & 31.0 & 17.4 \\
\hline Manual workers & 110 & 21.4 & 34.0 & 26.3 & 26.1 \\
\hline Employees & 243 & 17.7 & 20.9 & 25.2 & 17.3 \\
\hline Craftswomen & 2291 & 9.9 & 23.1 & 25.9 & 11.5 \\
\hline Farmers & 1078 & 13.6 & 39.1 & 14.6 & 18.2 \\
\hline
\end{tabular}

Table 3

Associations of alcohol abuse and smoking with occupational factors: adjusted odds ratios and $95 \%$ confidence intervals computed with logistic regression models.

\begin{tabular}{|c|c|c|c|c|c|c|c|c|}
\hline & \multicolumn{4}{|c|}{ Men $(n=6094)$} & \multicolumn{4}{|c|}{ Women $(n=7147)$} \\
\hline & \multicolumn{2}{|c|}{ Alcohol abuse } & \multicolumn{2}{|c|}{ Smoking } & \multicolumn{2}{|c|}{ Alcohol abuse } & \multicolumn{2}{|c|}{ Smoking } \\
\hline & OR & $95 \% \mathrm{CI}$ & OR & $95 \% \mathrm{CI}$ & OR & $95 \% \mathrm{CI}$ & OR & $95 \% \mathrm{CI}$ \\
\hline \multicolumn{9}{|l|}{ Age-adjusted $O R^{\mathrm{a}}$} \\
\hline Short-term employment & 1.25 & $1.03-1.51$ & 1.34 & $1.13-1.60$ & 1.25 & $0.99-1.58$ & 1.27 & $1.09-1.48$ \\
\hline Physical demands & 1.17 & $0.99-1.37$ & 1.50 & $1.30-1.73$ & 1.08 & $0.85-1.37$ & 1.21 & $1.04-1.40$ \\
\hline Psychological demands & 0.95 & $0.82-1.10$ & 1.18 & $1.04-1.35$ & 1.04 & $0.85-1.28$ & 1.45 & $1.27-1.65$ \\
\hline Job dissatisfaction & 1.24 & $1.06-1.46$ & 1.32 & $1.15-1.53$ & 1.23 & $0.98-1.54$ & 1.10 & $0.95-1.28$ \\
\hline \multicolumn{9}{|l|}{ Partially adjusted $O R^{\mathrm{b}}$} \\
\hline Short-term employment & 1.22 & $1.00-1.48$ & 1.25 & $1.05-1.49$ & 1.32 & $1.04-1.67$ & 1.20 & $1.02-1.40$ \\
\hline Physical demands & 1.10 & $0.93-1.30$ & 1.35 & $1.16-1.56$ & 1.25 & $0.98-1.60$ & 1.05 & $0.90-1.23$ \\
\hline Psychological demands & 0.97 & $0.83-1.12$ & 1.23 & $1.08-1.40$ & 0.96 & $0.78-1.18$ & 1.50 & $1.32-1.71$ \\
\hline Job dissatisfaction & 1.23 & $1.04-1.44$ & 1.30 & $1.12-1.50$ & 1.22 & $0.97-1.53$ & 1.07 & $0.93-1.25$ \\
\hline \multicolumn{9}{|l|}{ Fully adjusted $O R^{\mathrm{c}}$} \\
\hline Short-term employment & 1.25 & $1.02-1.52$ & 1.22 & $1.02-1.46$ & 1.36 & $1.07-1.72$ & 1.20 & $1.02-1.40$ \\
\hline Physical demands & 1.07 & $0.91-1.27$ & 1.32 & $1.14-1.54$ & 1.29 & $1.00-1.65$ & 1.06 & $0.91-1.24$ \\
\hline Psychological demands & 0.97 & $0.84-1.13$ & 1.23 & $1.08-1.41$ & 0.95 & $0.77-1.17$ & 1.49 & $1.30-1.70$ \\
\hline Job dissatisfaction & 1.23 & $1.05-1.45$ & 1.30 & $1.12-1.50$ & 1.24 & $0.98-1.55$ & 1.08 & $0.93-1.25$ \\
\hline \multicolumn{9}{|c|}{ Fully adjusted OR among managers ${ }^{\mathrm{d}}$} \\
\hline Short-term employment & 0.91 & $0.53-1.58$ & 1.01 & $0.62-1.67$ & 1.14 & $0.62-2.10$ & 1.38 & $0.86-2.21$ \\
\hline Physical demands & 1.17 & $0.62-2.22$ & 2.06 & $1.17-3.62$ & 1.99 & $1.03-3.83$ & 1.20 & $0.68-2.14$ \\
\hline Psychological demands & 1.10 & $0.79-1.54$ & 1.57 & $1.16-2.14$ & 0.97 & $0.63-1.49$ & 1.68 & $1.20-2.34$ \\
\hline Job dissatisfaction & 1.04 & $0.68-1.61$ & 0.92 & $0.61-1.38$ & 1.54 & $0.95-2.51$ & 0.98 & $0.64-1.50$ \\
\hline \multicolumn{9}{|c|}{ Fully adjusted OR among manual workers ${ }^{\mathrm{d}}$} \\
\hline Short-term employment & 1.16 & $0.82-1.63$ & 1.30 & $0.96-1.76$ & 0.62 & $0.23-1.71$ & 0.79 & $0.49-1.30$ \\
\hline Physical demands & 1.29 & $0.99-1.69$ & 1.45 & $1.15-1.84$ & 1.72 & $0.74-4.01$ & 1.23 & $0.77-1.97$ \\
\hline Psychological demands & 0.92 & $0.68-1.24$ & 1.03 & $0.79-1.35$ & 1.52 & $0.61-3.79$ & 1.32 & $0.80-2.18$ \\
\hline Job dissatisfaction & 1.20 & $0.90-1.62$ & 1.32 & $1.01-1.72$ & 0.82 & $0.33-2.04$ & 1.39 & $0.87-2.22$ \\
\hline
\end{tabular}

Bold type: significant odds ratios. In all models, missing values for educational levels were excluded, but missing values for income were included as a proper category.

a Adjusted for age, short-term employment, physical demands, psychological demands, job dissatisfaction

b Adjusted for age, short-term employment, physical demands, psychological demands, job dissatisfaction, and education, marital status, occupation, income.

c Adjusted for age, short-term employment, physical demands, psychological demands, job dissatisfaction, and occupational category, education, marital status, income.

d Adjusted for age, short-term employment, physical demands, psychological demands, job dissatisfaction, and education, marital status, income, occupational category. 

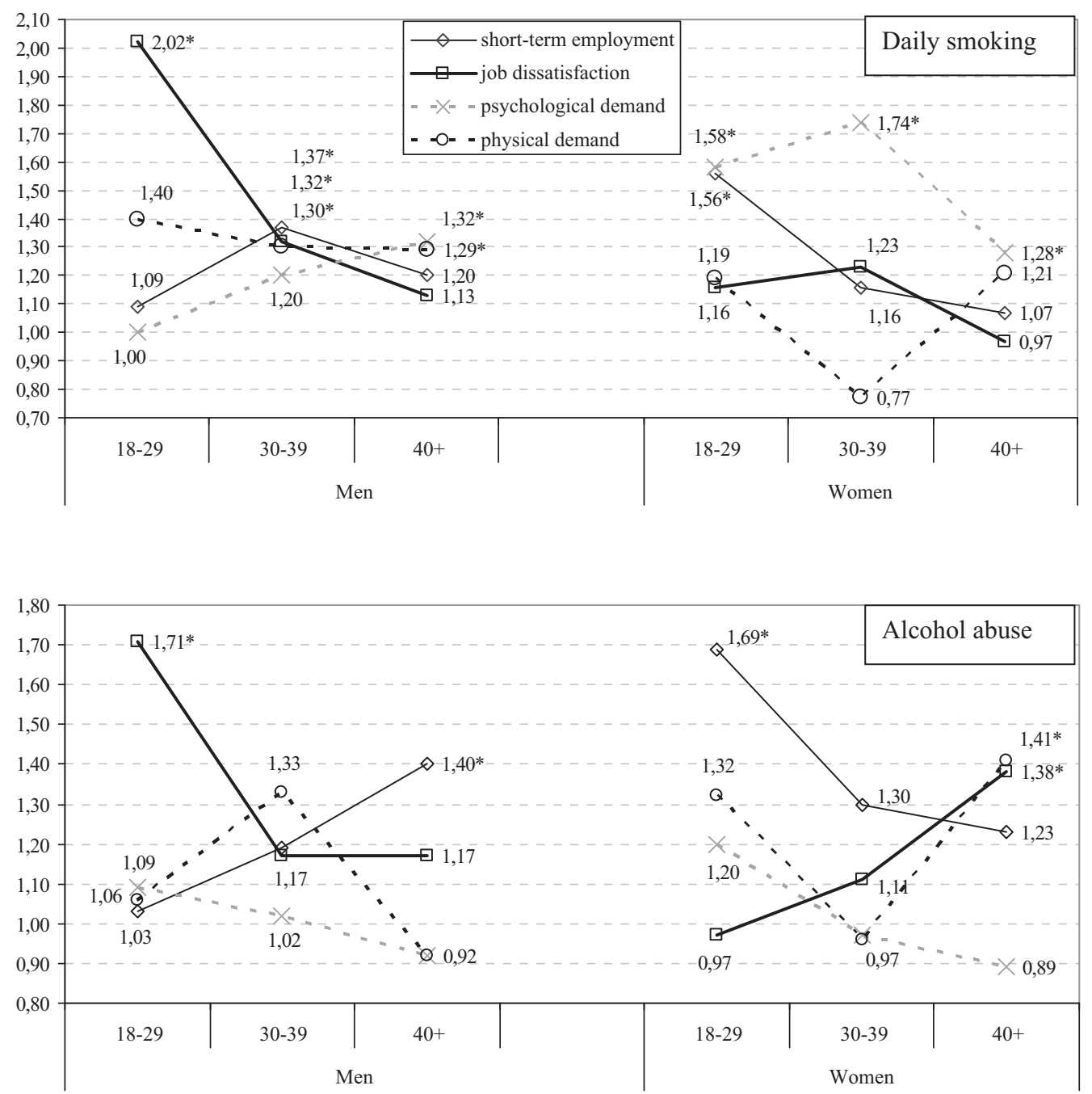

Fig. 1. Associations of alcohol abuse and smoking with occupational factors according to gender and age: odds ratios controlling for all covariates. Odds ratios were computed for each age group and each sex independently. They were adjusted for age (continuous), short-term employment, physical demands, psychological demands, job dissatisfaction, and educational level (missing values excluded), marital status, income (missing values included as a proper category), occupational category. *: significant odds ratio.

those with physically demanding jobs had a higher risk of alcohol abuse $(\mathrm{OR}=1.29)$, and those with psychologically demanding occupations a higher risk of smoking ( $O R=1.49)$. These results seem robust as they are globally valid for various adjustment levels. The stratified analysis shows contrasted results between manual workers and executives. Among managers, physical demands were strongly associated with smoking among males $(\mathrm{OR}=2.06)$ and with alcohol abuse among females $(\mathrm{OR}=1.99)$; psychological job demands was associated with daily smoking among males $(\mathrm{OR}=1.57)$ and females $(\mathrm{OR}=1.68)$. Among manual workers, physical job demands and job dissatisfaction were associated with daily smoking among males (respectively, $\mathrm{OR}=1.45$ and $\mathrm{OR}=1.32$ ).

Fig. 1 shows that these overall results varied across age groups. Among men, job dissatisfaction was related to smoking $(\mathrm{OR}=2.02)$ and alcohol abuse $(\mathrm{OR}=1.71)$ among young adults ( $<30$ years). A higher risk was also observed for smoking in men aged 30-39 (OR = 1.32). Physical and psychological demands were related to smoking among the men aged 40 or older (ORs around 1.30). Short-term employment was related to smoking among the men aged $30-39(\mathrm{OR}=1.37)$ and to alcohol abuse among those aged 40 and older $(\mathrm{OR}=1.40)$. In women, a physically demanding job and job dissatisfaction were related to alcohol abuse among the subjects aged 40 or older (OR, around 1.4). Psychological demands were related to smoking among the subjects aged 1829 and 30-39 (OR 1.58 and 1.74, respectively), and to a lesser degree among those 40 years old or older $(\mathrm{OR}=1.28)$. Shortterm employment was related to smoking $(\mathrm{OR}=1.56)$ and alcohol abuse $(\mathrm{OR}=1.69)$ among young adults, with a similar decreasing trend for both substances across the age groups.

Finally, smoking within 5 min of waking affected $11.0 \%$ of male smokers and $8.7 \%$ of female smokers $(p<0.01)$. Table 4 shows its strong association with all occupational factors in both sexes with age-adjusted ORs of 1.26-1.66. Adjustment for all covariates reduced the ORs but they remained significant for the two sexes combined (except for psychological job 
Table 4

Associations of smoking on waking ${ }^{\mathrm{a}}$ with occupational factors among daily smokers: adjusted odds ratios ${ }^{\mathrm{a}}$ and $95 \%$ confidence intervals.

\begin{tabular}{|c|c|c|c|c|c|c|}
\hline \multirow[b]{2}{*}{$\operatorname{Men}(n=3403)$} & \multicolumn{2}{|c|}{$\begin{array}{l}\text { Age-adjusted }{ }^{\mathrm{b}} \text { OR and } 95 \% \\
\text { CI }\end{array}$} & \multicolumn{2}{|c|}{$\begin{array}{l}\text { Partially adjusted }{ }^{\mathrm{c}} \text { OR and } \\
95 \% \text { CI }\end{array}$} & \multicolumn{2}{|c|}{$\begin{array}{l}\text { Fully adjusted }{ }^{\mathrm{d}} \text { OR and } \\
95 \% \mathrm{CI}\end{array}$} \\
\hline & & & & & & \\
\hline Short-term employment & 1.51 & $1.00-2.26$ & 1.42 & $0.94-2.14$ & 1.40 & $0.92-2.12$ \\
\hline Physical demands & 1.46 & $1.05-2.03$ & 1.42 & $1.01-2.00$ & 1.64 & $1.18-2.27$ \\
\hline Psychological demands & 1.48 & $1.08-2.04$ & 1.55 & $1.12-2.14$ & $1.35 \S$ & $0.95-1.93$ \\
\hline Job dissatisfaction & 1.26 & $0.89-1.77$ & 1.26 & $0.89-1.78$ & 1.23 & $0.87-1.74$ \\
\hline \multicolumn{7}{|l|}{ Women $(n=3234)$} \\
\hline Short-term employment & 1.55 & $1.06-2.27$ & 1.46 & $1.00-2.15$ & 1.50 & $1.01-2.22$ \\
\hline Physical demands & 1.61 & $1.10-2.38$ & 1.53 & $1.03-2.27$ & 1.09 & $0.75-1.58$ \\
\hline Psychological demands & 1.49 & $1.02-2.19$ & 1.31 & $0.88-1.95$ & 1.23 & $0.82-1.85$ \\
\hline Job dissatisfaction & 1.00 & $0.70-1.44$ & 1.05 & $0.73-1.52$ & $1.39 \S$ & $0.94-2.06$ \\
\hline \multicolumn{7}{|c|}{ Both genders combined $(n=6437)$} \\
\hline Short-term employment & 1.54 & $1.17-2.04$ & 1.45 & $1.10-1.93$ & 1.42 & $1.07-1.89$ \\
\hline Physical demands & 1.44 & $1.12-1.84$ & 1.33 & $1.03-1.72$ & 1.37 & $1.08-1.75$ \\
\hline Psychological demands & 1.25 & $0.99-1.59$ & 1.31 & $1.03-1.67$ & $1.27 \S$ & $0.97-1.65$ \\
\hline Job dissatisfaction & 1.37 & $1.06-1.77$ & 1.34 & $1.04-1.73$ & 1.32 & $1.02-1.70$ \\
\hline
\end{tabular}

Bold type: significant odds ratios. §Close to significance $(p<0.10)$. In all models, missing values for educational levels are excluded, but missing values for income are included as a proper category.

a Smoking $\leq 5$ min (vs. later) after waking.

b Adjusted for age, short-term employment, physical demands, psychological demands, job dissatisfaction.

c Adjusted for age, short-term employment, physical demands, psychological demands, job dissatisfaction, and education, marital status, income.

d Adjusted for age, short-term employment, physical demands, psychological demands, job dissatisfaction, and education, marital status, income, occupational category.

demands). This result suggests that the occupational factors also play a role in nicotine addiction among smokers.

\section{Discussion}

\subsection{Findings}

Higher risks for alcohol abuse and smoking were observed among the workers with physical/psychological job demands, job dissatisfaction, and short-term employment. These associations greatly differed between genders and age groups, a key result in this study. Additionally, smoking on waking was much more common among smokers with these occupational factors.

First, we found that the workers of both genders with shortterm employment were subject to a much higher risk for both alcohol abuse and smoking $[4,10]$. These findings suggest that workers with short-term employment may consume alcohol or tobacco to cope with their occupational problems and job insecurity [38-40]. People in this situation are often in poor economic and housing conditions and consider smoking to be a cheap leisure activity and compensation for their living conditions [11]. More importantly, clear gender and age disparities were observed. Strong associations of alcohol abuse and smoking with short-term employment were found among men aged 30 years and older and among women aged less than 30 when controlling for occupational factors and socioeconomic covariates. We conducted additional analyses to interpret this result. Among people aged less than 30, women more often than men reported living in their own house $(76.5 \%$ vs. $61.1 \%$; $p<0.001)$ or having a child $(30.1 \%$ vs. $18.4 \%$; $p<0.0001)$. This means that more women than men could depend on their job security for their housing and could decide to have a child; and single parents are more likely to be women. The strong association between short-term employment and alcohol abuse among older men may reflect the important role of a man's occupation and earnings in the household when children are growing up and have increasing needs. People with short-term employment may feel psychological discomfort due to job loss fear as older unemployed people have greater problems finding a new job. Consequently, the results in Fig. 1 appear robust and, to our knowledge, this has never been reported in the literature.

Second, men with job dissatisfaction were subject to a high risk for alcohol abuse and smoking, but not women, despite significant bivariate relations. The risk patterns differed markedly between age groups. It was very high among young adults for alcohol abuse and for smoking, less high among the subjects aged 30-39 for smoking, not significant for older ages in males and only significant for alcohol abuse among the oldest age group ( $\geq 40$ years) among females. These patterns could reflect greater work-related difficulties or occupational exposure [10], a lack of experience or job knowledge, and possibly higher job expectations among young workers in the male subpopulation. To our knowledge, this contrast between genders has never been shown.

Third, people with high job demands had higher risks of smoking/alcohol abuse, which is coherent with the results in occupational epidemiology. These people initiate smoking or smoke more intensively before age 30 or during the first years on the job $[10,13,41]$. So either substance use was initiated 
during adolescence or adverse occupational demands can increase it, as found for smoking after waking. The higher risk found for workers aged less than 30 and age 40 or older were expected according to our hypotheses. As stated earlier, young adults are particularly at risk for adverse working conditions and substance use. The reasons may also include escape from job stress and problem relationships $[42,43]$, leading to performance-enhancing behavior [41], which may be more common in these individuals than in the other groups. None of our results were modified when independent housing or having a child were introduced in the models. Additionally, the strong associations found for smoking in the $5 \mathrm{~min}$ after waking and occupational factors suggest that they may generate tobacco dependence and not only a higher risk of smoking to cope with difficulties in the workplace.

Our results support the gender/age variations in the occupational factor-resource imbalance [23]. Physically and psychologically demanding jobs were not linked with alcohol abuse, but with smoking among men aged 30 and over only. In contrast, psychologically demanding work was not associated with alcohol abuse among women, but strongly related to smoking among both men and women aged less than 30 or 30 39. Physically demanding work was related to alcohol abuse among women aged 40 and older.

\subsection{Comparisons with other studies}

Our findings are consistent with those reported by other studies. One study on bank and university nonmanual employees in Britain showed very small effects of lack of job stimulation on smoking and heavy alcohol consumption (OR 1.1) [23]. Our study exhibits much higher associations. One study in the Dutch labor force found that lack of job control was an important risk factor for smoking among men but not women [26]. Our results agreed with this as we found that physically demanding work and job dissatisfaction were associated with smoking among men only. A recent study in Quebec workers found that workplace harassment is an important factor associated with alcohol use and misuse, but it did not investigate the gender-age disparities [12].

\subsection{Limitations}

First, the cross-sectional design excludes interpretation in terms of causality. However, most workers have one main job during their working life [27], and the socioeconomic covariates (education, occupation, income level) would not change for most subjects throughout life [27]. Early alcohol use can decrease academic performance at school $[44,45]$ and lead to adverse occupational situations [46], but such situations should be rare since less than $1 \%$ of the adolescents aged 17 drink alcohol on a daily basis [2] and less than $1 \%$ of the French population suffers from alcohol dependence [47]. Nevertheless, people using tobacco or alcohol could also be more sensitive to occupational factors, which could explain a part of the present results.

Second, although self-administered occupational health history questionnaires are generally considered reliable
$[48,49]$, the acceptance of the questions dealing with alcohol and tobacco use may vary with the socioeconomic status of the respondent, which may lead to biased prevalence estimates. However, this should have a small impact on the association patterns that proved to be significant with various levels of adjustment. Similarly, the question on physically demanding work is general and may consider all occupational hazards that can generate fatigue: biomechanical and physical exposures, which are more of a concern in manual jobs, as well as long working hours, standing and walking, repeated meetings, etc. This could explain why a physically demanding job was found to increase the risk of smoking and alcohol abuse among executives. Potentially sensitive to different occupational conditions, this approach appeared to be an advantage given that the question is relevant for all occupational categories, which can thus be compared in a single model.

Third, this study focused on French-speaking people with a land phone line (whether or not they also had a cellular phone). In the survey, young people and males were slightly overrepresented among people having only a cell phone. In a multivariate model adjusting for various sociodemographic characteristics, they showed higher risks for daily smoking $(\mathrm{OR}=1.8)$ and alcohol abuse $(\mathrm{OR}=1.4)[50]$. However, this bias should be small because we aimed at measuring associations and it is likely that they would have tended in the same direction as those observed here and because people having only cell phones account for less than $14 \%$ of the French population. Another selection bias may have occurred as the response rate was $63 \%$, but this rate is high for a telephone survey [51] and non-response bias in health surveys is generally small [52].

The strengths of the study also deserve to be mentioned. The sample was derived from the general population, making generalization possible for the population in France. The sample size allowed us to study men and women as well as three main age groups of working life separately, which may be crucial in occupational epidemiology.

\section{Conclusion}

People with short-term employment or occupational demands were subject to higher risks of alcohol abuse, smoking, and nicotine dependence, with high gender and age disparities. Job dissatisfaction and short-term employment play important roles at the beginning and in the last part of working life. Large-scale preventive measures focusing on specific occupational factors of these groups may be useful to limit alcohol and tobacco use in the French working population.

\section{Disclosure of interest}

The authors declare that they have no conflicts of interest concerning this article.

\section{References}

[1] Dahlgren G, Whitehead M. Levelling up (Part 2): a discussion paper on European strategies for tackling social inequities in health. Studies on 
Social and Economic determinants of Population. Vol. 3. 2006, Copenhagen: World Health Organization Regional Office for Europe.

[2] Legleye S, Spilka S, Le Nézet O, et al., Les drogues à 17 ans - Résultats de l'enquête ESCAPAD 2008 [Drug use of the 17 years old - Results of the 2008 ESCAPAD survey] Tendances, 2009;66. http://www.ofdt.fr/BDD/ publications/docs/eftxstp6.pdf.

[3] Peto R, Lopez A, Boreham J, et al. Mortality from smoking in developed countries 1950-2000. (2nd edition: data updated 9 December 2005) 2005 [cited 2008]; available from: http://rum.ctsu.ox.ac.uk/ tobacco/.

[4] Baumann M, Spitz E, Guillemin F, et al. Associations of social and material deprivation with tobacco, alcohol, and psychotropic drug use, and gender: a population-based study. Int J Health Geogr 2007;9:6-50.

[5] Bourgkard E, Wild P, Massin N, et al. Association of physical job demands, smoking and alcohol abuse in subsequent premature mortality: a 9-year follow-up population-based study. J Occup Health 2008;50: $31-40$.

[6] Benach J, Solar O, Vergara M, et al. Six employment conditions and health inequalities: a descriptive overview. Int J Health Serv 2010;40(2):269-80. http://www.ncbi.nlm.nih.gov/entrez/query.fcgi?cmd=Retrieve \&db=PubMed\&dopt=Citation\&list_uids=20440970.

[7] Niedhammer I, Chastang JF, David S, et al. The contribution of occupational factors to social inequalities in health: findings from the national French SUMER survey. Soc Sci Med 2008;67(11):1870-81. http// www.ncbi.nlm.nih.gov/entrez/query.fcgi?cmd=Retrieve \&db=PubMed\&dopt $=$ Citation\&list_uids $=18851892$.

[8] Chau N, Mur J, Touron C, et al. Correlates of occupational injuries for various jobs in railway workers: a case-control study. J Occup Health 2004;46:272-80.

[9] Lawler K, Schmied L. The relationship of stress, type A behavior and powerlessness to physiological responses in female clerical workers. J Psychosom Res 1987;31:555-66.

[10] Chau N, Choquet M, Falissard B, et al. Relationship of physical job demands to initiating smoking among working people: a population-based cross-sectional study. Ind Health 2009;47(3):319-25. http://www.ncbi. nlm.nih.gov/entrez/query.fcgi? $\mathrm{cmd}=$ Retrieve $\& \mathrm{db}=$ PubMed \&dopt=Citation\&list_uids $=19531918$.

[11] Peretti-Watel P, Constance J. It's all we got left". Why poor smokers are less sensitive to cigarette price increases. Int J Environ Res Public Health 2009;6(2):608-21. http://www.ncbi.nlm.nih.gov/entrez/query.fcgi?cm$\mathrm{d}=$ Retrieve $\& \mathrm{db}=$ PubMed\&dopt $=$ Citation\&list_uids $=19440404$.

[12] Marchand A. Alcohol use and misuse: what are the contributions of occupation and work organization conditions? BMC Public Health 2008;8:333. http://www.ncbi.nlm.nih.gov/entrez/query.fcgi?cmd=Retrieve $\& \mathrm{db}=$ PubMed $\&$ dopt $=$ Citation\&list_uids $=18816388$.

[13] Peretti-Watel P, Constance J, Seror V, et al. Working conditions, job dissatisfaction and smoking behaviours among French clerks and manual workers. J Occup Environ Med 2009;51(3):343-50. http://www.ncbi. nlm.nih.gov/entrez/query.fcgi?cmd=Retrieve $\& \mathrm{db}=$ PubMed $\&$ dopt=Citation\&list_uids $=19225420$.

[14] Chau N, Wild P, Dehaene D et al. (2010), Roles of age, length of service and job in work-related injury: a prospective study of 446120 personyears in railway workers, Occup Environ Med, 67(3):147-153.

[15] Chau N, Mur J, Benamghar L, et al. Relationships between certain individual characteristics and occupational accidents for various jobs in the construction industry: a case-control study. Am J Ind Med 2004;45: 84-92.

[16] Allen T, Romans F. Labour Force Survey 2005 - Employment rate in the EU25 was $63.8 \%$ in 2005 - One in seven employees had a temporary job. Luxemburg: Eurostat; 2006.

[17] Benach J, Castedo A, Solar O, et al. Methods for the study of employment relations and health inequalities in a global context. Int J Health Serv 2010;40(2):209-13. http://www.ncbi.nlm.nih.gov/entrez/query.fcgi?cm$\mathrm{d}=$ Retrieve $\& \mathrm{db}=$ PubMed\&dopt $=$ Citation\&list_uids $=20440965$.

[18] Artazcoz L, Borrell C, Cortes I, et al. Occupational epidemiology and work related inequalities in health: a gender perspective for two complementary approaches to work and health research. J Epidemiol Community Health 2007;61(Suppl. 2):ii39-45. http://www.ncbi.nlm.nih.gov/entrez/query. fcgi?cmd=Retrieve $\& d b=$ PubMed\&dopt=Citation\&list_uids=18000116.
[19] INSEE. [Men and women: focus on gender differences and roles] Femmes et hommes: regards sur la parité. INSEE-références. Paris: INSEE; 2008, 238 pp..

[20] Legleye S, Beck F, Peretti-Watel P, et al. Role of employment or scholar status and gender: Drug use among 18- to 25-year-olds in France in 2005. Revue Epidemiol Sante Pub 2008;56(5):345-55. http://www.ncbi.nlm.nih.gov/entrez/query.fcgi?cmd=Retrieve \&db=PubMed\&dopt=Citation\&list_uids=18945566.

[21] Peretti-Watel P, Legleye S, Baumann M, et al., Fatigue, insomnia and nervousness: gender disparities and roles of individual characteristics and lifestyle factors among economically active people. Soc Psychiatry Psychiatr Epidemiol 2009. doi:10.1007/s00127-008-0487-x.

[22] Wilsnack RW, Wilsnack SC, Kristjanson AF, et al. Gender and alcohol consumption: patterns from the multinational GENACIS project. Addiction 2009:104(9):1487-500. http://www.ncbi.nlm.nih.gov/entrez/query.fcgi?cmd=Retrieve $\& \mathrm{db}=$ PubMed $\&$ dopt $=$ Citation $\&$ lis t_uids $=19686518$.

[23] Emslie C, Hunt K, Macintyre S. How similar are the smoking and drinking habits of men and women in non-manual jobs? Eur J Public Health 2002;12:22-8.

[24] Roxburgh S. Gender differences in the effect of job stressors on alcohol consumption. Addict Behav 1998;23(1):101-7.

[25] Cho YI. Gender composition of occupation and industry on working women's alcohol consumption. J Studies Alcohol 2004;65(3):345-52.

[26] Otten F, Bosma H, Swinkels H. Job stress and smoking in the Dutch labour force. Eur J Public Health 1999;9(1):58-61.

[27] Chau N, Bourgkard E, Bhattacherjee A, et al. Associations of job, living conditions and lifestyle with occupational injury in working population: a population-based study. Int Arch Occup Environ Health, 2008;81(4):37989. http://www.ncbi.nlm.nih.gov/entrez/query.fcgi?cmd=Retrieve $\& d b=-$ PubMed\&dopt=Citation\&list_uids $=17701420$.

[28] Park MJ, Paul Mulye T, Adams SH, et al., The health status of young adults in the United States. J Adolesc Health, 2006;39(3):305-17. http:// www.ncbi.nlm.nih.gov/entrez/query.fcgi?cmd=Retrieve\&db=PubMed \&dopt=Citation\&list_uids $=16919791$.

[29] Chau N, Ravaud JF, Otero-Sierra C, et al., Prevalence of impairments and social inequalities. Rev Epidemiol Sante Publique, 2005;53(6):614-28. http://www.ncbi.nlm.nih.gov/entrez/query.fcgi?cmd=Retrieve $\& d b=P u b-$ Med\&dopt=Citation\&list_uids=16434934.

[30] Chau N, Gauchard G, Dehaene D, et al. Contributions of occupational hazards and human factors in occupational injuries and their associations with job, age and type of injuries in railway workers. Int Arch Occup Environ Health 2007;80:517-25.

[31] Courvoisier D, Etter JF, Using item response theory to study the convergent and discriminant validity of three questionnaires measuring cigarette dependence. Psychol Addict Behav 2008;22(3):391-401. http:// www.ncbi.nlm.nih.gov/entrez/query.fcgi?cmd=Retrieve \&db=PubMed\&dopt=Citation\&list_uids $=18778132$.

[32] Beck F, Gautier A, Guilbert P. Baromètre santé 2005. Attitudes et comportements de santé. Coll. Baromètre santé ed.. Saint-Denis: INPES; 2007. p. 608.

[33] Bush K, Kivlahan D, Mc Donell M, et al. The AUDIT alcohol consumption questions (AUDIT-C): An Effective Brief Screening Test for Problem Drinking. Arch Intern Med 1998;158:1789-95.

[34] Niedhammer, I., J.F. Chastang, and S. David, Importance of psychosocial work factors on general health outcomes in the national French SUMER survey. Occup Med (Lond) 2008;58(1):15-24. http://www.ncbi.nlm.nih. gov/entrez/query.fcgi?cmd=Retrieve $\& \mathrm{db}=$ PubMed $\&$ dopt $=$ Citation\&list_ uids $=17965447$.

[35] Niedhammer I, Bourgkard E, Chau N, Occupational and behavioural factors in the explanation of social inequalities in premature and total mortality: a 12.5-year follow-up in the Lorhandicap study. Eur J Epidemiol http://www.ncbi.nlm.nih.gov/entrez/query.fcgi?cmd=Retrieve \&db= PubMed\&dopt=Citation\&list_uids $=20845063$.

[36] Schaap MM, Kunst AE. Monitoring of socio-economic inequalities in smoking: learning from the experiences of recent scientific studies. Public Health 2009;123(2):103-9. http://www.ncbi.nlm.nih.gov/entrez/query. fcgi?cmd=Retrieve \&db=PubMed\&dopt=Citation\&list_uids=19147163. 
[37] UNESCO. International standard classification of education 1997. Montreal: UNESCO; 1997.

[38] Virtanen M, Kivimaki M, Joensuu M, et al. Temporary employment and health: a review. Int J Epidemiol 2005;34(3):610-22. http://www.ncbi.nlm .nih.gov/entrez/query.fcgi? $\mathrm{cmd}=$ Retrieve $\& \mathrm{db}=$ PubMed $\&$ dopt=Citation $\&$ list_uids=15737968.

[39] Virtanen M, Kivimäki M, Ferrie J, et al. Temporary employment and antidepressant medication: a register linkage study. J Psychatric Res 2008;42:221-9.

[40] Cavelaars A, Kunst A, Mackenbach J. Socio-economic differences in risk factors for morbidity and mortality in the European Community: an international comparison. J Health Psychol 1997;2:253-372.

[41] Gay V, Houdoyer E, Rouzaud G. Taking drugs for performance-enhancing at job: a study in a sample of workers in Paris. Therapie 2008;63(6):45362. http://www.ncbi.nlm.nih.gov/entrez/query.fcgi?cmd=Retrieve $\& d b=$ PubMed\&dopt=Citation\&list_uids $=19236835$.

[42] Grunberg L, Moore S, Anderson-Connolly R, et al. Work stress and selfreported alcohol use: the moderating role of escapist reasons for drinking. J Occup Health Psychol 1999;4(1):29-36. http://www.ncbi.nlm.nih.gov/ entrez/query.fcgi?cmd=Retrieve $\& \mathrm{db}=$ PubMed\&dopt=Citation\&list_uids $=10100111$.

[43] Grunberg L, Moore S, Greenberg ES. Work stress and problem alcohol behavior: a test of the spillover model. J Organ Behav 1998; $19(5)$.

[44] Aertgeerts B, Buntinx F. The relation between alcohol abuse or dependence and academic performance in first-year college students. J Adolesc Health 2002;31(3):223-5. http://www.ncbi.nlm.nih.gov/entrez/query. fcgi?cmd=Retrieve $\& d b=$ PubMed\&dopt=Citation\&list_uids=12225733.
[45] Arrellano CM, Chavez EL, Deffenbacher JL. Alcohol use and academic status among Mexican American and white non-Hispanic adolescents. Adolescence 1998;33(132):751-60.

[46] Ellickson, P.L., J.S. Tucker, and D.J. Klein, Ten-year prospective study of public health problems associated with early drinking. Pediatrics, 2003;111(5 Pt 1):949-55. http://www.ncbi.nlm.nih.gov/entrez/query.fcgi $? \mathrm{cmd}=$ Retrieve $\& \mathrm{db}=$ PubMed $\&$ dopt $=$ Citation\&list_uids $=12728070$.

[47] Legleye S, Beck F. Alcool: une baisse sensible des niveaux de consommation. In: Beck F, Gautier A, Guilbert P, editors. Baromètre santé 2005. St Denis: INPES; 2007. p. 112-54.

[48] Lewis RJ, Friedlander BR, Bhojani FA, et al. Reliability and validity of an occupational health history questionnaire. J Occup Environ Med 2002;44(1):39-47. http://www.ncbi.nlm.nih.gov/entrez/query.fcgi?cm$\mathrm{d}=$ Retrieve $\& \mathrm{db}=$ PubMed\&dopt=Citation\&list_uids=11802464.

[49] Kenkel D, Lillard DR, Mathios A, Smoke or fog? The usefulness of retrospectively reported information about smoking. Addiction 2003;98(9):1307-13. http://www.ncbi.nlm.nih.gov/entrez/query.fcgi?cm$\mathrm{d}=$ Retrieve $\& \mathrm{db}=$ PubMed\&dopt=Citation\&list_uids=12930218.

[50] Beck F, Legleye S, Spilka S. Cannabis, cocaïne, ecstasy: entre expérimentation et usage régulier. In: Beck F, Gautier A, Guilbert P, editors. Baromètre santé 2005. St Denis: INPES; 2007. p. 168-221.

[51] Alonso J, Angermeyer M, Bernert S, et al. Psychotropic drug utilization in Europe: results from the European Study of the Epidemiology of Mental Disorders (ESEMeD) project. Acta Psychiatrica Scandinavia 2004; Suppl.:55-64.

[52] Kant I, Bültmann U, Schröer K, et al. An epidemiological approach to study fatigue in the working population: the Maastricht Cohort Study. Occup Environ Med 2003;60(Suppl. I):i32-9. 